\title{
Kurdish nationalism from an Islamist perspective: the discourses of Turkish Islamist writers
}

\section{Umit Cizre Sakallioglu}

To cite this article: Umit Cizre Sakallioglu (1998) Kurdish nationalism from an Islamist perspective: the discourses of Turkish Islamist writers, Journal of Muslim Minority Affairs, 18:1, 73-89, DOI: 10.1080/13602009808716394

To link to this article: https://doi.org/10.1080/13602009808716394

曲 Published online: 20 Mar 2007.

Submit your article to this journal 중

Џlll Article views: 342

Citing articles: 11 View citing articles 주 


\section{Kurdish Nationalism From an Islamist Perspective: The Discourses of Turkish Islamist Writers}

\section{UMIT CIZRE SAKALLIOGLU}

\section{Introduction}

In the wake of the twenty-first century, the nationalism of Turkey's Kurdish population-in popular parlance, the 'Kurdish problem'-continues to be a priority concern in Turkish politics as well as in the international arena. There is no doubt that the problem stems from historical root causes which requires analysis of the political processes of state domination, Turkish nationalism and uneven modernization. However, the escalation of the movement for Kurdish nationalism in the last decade reflects deep changes on domestic and international levels. Foremost among them is the impact of the 1991 Gulf War and of globally powerful ideas concerning identity, difference, cultural and human rights.

Spurred and disturbed by the ongoing conflict, ${ }^{\star}$ substantial sections of Turkish civil society and some members of the political elite have started to question the Republican political codes, norms and practices by reaching out beyond Turkey's boundaries for global concepts such as pluralism, multiculturalism, accountable government and the rule of law. The country is, in fact, redefining its 'being' in image and in reality vis-a-vis its past and future, with the Kurdish issue playing an integral part. The Kurdish issue has become a central component of the process of redefining Turkish identity.

\section{The Role of Islamist Writers in Redefining Kurdish Nationalism}

The self-examination process which the Kurdish situation has sparked is not just one among secular intellectuals and political elites. It has also engaged the minds of Islamist actors whose interest in and appreciation of the Kurdish question took shape in the 1990 s, after it became radicalized. The central objective of this article is not to analyze the evolution, nature and implications of Kurdish nationalism. Rather, it is to examine the intellectual motives and tools employed by a group of Islamist writers to understand, define and influence Kurdish nationalism by reconfiguring Islam. Essentially, this article seeks to analyze the ways in which contemporary Islamist writers formulate the relation of Islam to the notion of nationalism in general and Kurdish nationalism in particular. Furthermore, it tries to show how these writers envisage the role of Islam $v i s-\grave{a}$-vis Kurdish nationalism by asking whether or not Islam is a force superseding Kurdish particularism, ethnicity being the fundamental one, or unwittingly lending support to Kurdish nationalism by being the chief marker of past and present Kurdish identity.

First, however, a few clarifications are in order. It could be claimed with some degree

*At the time of this writing, state security forces were claiming to have broken the core strength of Syria-based operations of the Kurdistan Workers' Party (PKK). However, a political settlement of the conflict which has cost 22,000 lives since 1984 is not yet in sight. 
of accuracy that the Kurdish question has become the catalyst through which the Islamist camp as a whole is laying out its ideational-theoretical parameters on nationalism in general, Turkish and Kurdish nationalisms in particular. In view of the relatively underdeveloped state of Islamist thinking on the theory and practice of nationalism in general, setting out to analyze and systematize the discourses of Islamist writers on the specific question of nationalism is a difficult task. Furthermore, the terrain on which the Islamist writers are working is fluid due to the absence of a fixed and singular Islamist movement which holds a coherent and unified view on the nature and implications of the Kurdish conflict. An additional complexity is the obvious lack of clarity in Kurdish nationalist discourse with regard to its nature, demands and political vision. When all of these are added together, Islamist writing on Kurdish nationalism should be set within a theoretical environment neither too rigorous, nor coherent or systematic in trying to come to terms with its problematic. In a sense, it follows that the discourses of the writers show as many differences as similarities on the Kurdish question, that, as a result, it is sometimes difficult to systematize their writings.

\section{Profile of Islamist Writers}

There are 12 Islamist writers ${ }^{1}$ chosen for this essay. The criterion for choosing them was based on the frequency with which they treated various aspects of Kurdish nationalism in their writings since 1990 . On an empirical level, then, they are the most prominent names that appeared in the Islamist network of media on the strength of their higher motivation to deal with the issue more or less systematically after the issue seemed to prove its durability in the 1990s. Of the Islamist writers, about half are Kurdish by origin. ${ }^{2}$ Since the position of Kurdish writers as subjects of what they try to explain coincides with the object of their study, it is crucial to raise the question whether it is their ethnic Kurdishness or Islamic credentials that condition their understanding of Kurdish ethno-nationalism. It will be made clear in the course of the article that Kurdish-Islamist writers tend to search for a 'space' for Kurdish ethnic distinctiveness within the framework of the suggested formula of ummah, the Islamic community of the faithful, while the position of the Turkish-Islamist writers leans heavily toward defending the integrity of the Turkish state rather than to acknowledging a Kurdish ethnic distinctiveness. The discourses of Kurdish-Islamist writers add yet another-admittedly extremely important-variation to the existing diversity of cognitive maps of Islamist authors.

\section{The Importance of Islamist Writers ${ }^{3}$}

It is true that there are, at present, a multitude of Islamic actors and platforms with clashing views and shifting interpretations of the Kurdish conflict. Sufi tarikats (brotherhoods), Islamic communities, the now outlawed pro-religious Welfare Party (WPRefah Partisi) which scored its second largest share of regional votes in the eastern and southwestern regions, ${ }^{4}$ the Turkish state, and even the PKK leadership ${ }^{5}$ have all been using Islamic language and symbols ${ }^{6}$ to inject a degree of legitimacy into their discourses and actions. This is a confirmation of the belief on the part of these actors that Islam wields a strong influence in the region and is an effective instrument of legitimation.

Of the multitude of Islamic voices, the Islamist writers of present day Turkey constitute an important and powerful category of actors who are somewhat dis- 
tinguished from the 'Muslim intellectuals'. These writers write columns in Islamic newspapers and journals, and/or they author books or/and appear on Islamist radio and TV channels. Unlike the Muslim intellectuals who are basically engaged in 'reconstructing' the essentials of Islam, these authors 'disseminate' their views on topical issues of interest with a view to raising Islamic consciousness to a higher level and sensitizing Muslim readers to religious perspectives in the interpretation of internal and external events. However, the borderline between being called a 'Muslim intellectual' and 'Muslim writer' is often a rather thin and not a very useful one to draw. In a fast changing domestic and external world, these writers have become extremely influential agents through which Islam correlates with the pressing needs of the time and addresses the dynamic issues of contemporary Turkey. Together with the Muslim intellectuals, the writers emerge quite strongly in tone and achieve to build public images and enjoy popularity not experienced by earlier writers. Although their level of political engagement is higher than the intellectuals of Islamist persuasion, they also reconstruct and remold Islam in addressing new realities.

The post cold war landscape provided the context for the increasing public visibility of Islam in Turkey. On the one hand, the official ideology of the Republic, Kemalism (the word is derived from the name of the founder of the Turkish Republic, Mustafa Kemal Ataturk) lost its unchallenged supremacy as a comprehensive social and political programme which aimed at modernizing Turkey. This project denied any role for Islam in the public sphere. Turkey's increased integration with the world after the last military coup in 1980 created new dislocations, demands and hopes. Turkish politics was caught up in a paradox: while the political class and institutions failed to process new demands and thus narrowed the political space to preempt opposition, globalization had already made 'new ideas' easily available to common people through a revolution in information technologies and mass media. The political space, in other words, was simultaneously expanded to make room for new voices by a touch of the invisible hand of globalization. This meant that Kemalism, as a strategy of controlled modernization, failed to cope with the newly emerging politico-social complexity and to provide as meaningful a framework as it did in the past. The rising role of Islamist writers in Turkey in the last decade and a half should, therefore, be related to the emergence of Islam in the public space as a credible public ideology, and an alternative to Kemalism.

Apart from the changed political economy of Turkey in the post cold war era, there is then a global dimension for the increasing salience of Islam and Islamist writers. A useful concept which can explain the rising significance of reinterpretation of Islamic faith in politics in Muslim societies is what Eickelman and Piscatori call the 'objectification of Islamic consciousness'. ${ }^{7}$ To put it briefly, according to this concept, the end of bipolarity and the cold war politics have provided the context for the critical moment of change in the Islamist writer's texts: an accelerated process of mass communication, mass higher education and publishing have already made Islamic texts available and accessible to the masses, breaking the monopoly of the tradition-oriented ulama to transmit and interpret Islamic ideas in many Muslim countries. Direct and broader access to the printing world has enabled a 'process by which basic questions came to the fore in the consciousness of a large number of believers ... these explicit, widely shared and objective questions are modern queries that increasingly shape the discourse and practice of Muslims of all social classes' ${ }^{8}$ More importantly, for Eickelman and Piscatori, the objectification of Islam also means systematization of religious, as opposed to non-religious canons, that is, drawing the boundaries between what is Islamic and what is not. Once religious traditions are transformed into a conscious and 
objective system and a guide for political conduct, 'the question of who speaks for an objectified Islam' becomes central to Muslim politics. ${ }^{9}$

According to this explanation then, the current importance of Islamist writers must be sought in the intense impact which the text/print has on Muslim consciousness. The resulting need to find Islamic responses to modern questions has contributed to the rising significance of Islamist intellectuals and writers who appropriate modernity on Islamic terms. One implication of the 'objectification' thesis, however, should be that the questions people ask, the people themselves and the answers are important components of this process. Different questions are asked in different contexts by the same people, who then attach different meanings to the answers. Similarly, different answers are provided at different points of time. All these point to the fact that the questions asked and the answers given are embedded in a particular social reality. What draws the line between what is Islamic and what is not is the reality which changes through time. Canons of systematized Islam are more products of the times than fixed sources of Islamic persuasion.

Those who ask the questions are now part of a new and complex middle-class with a history of immigration from rural to provincial centers-a component of Turkey's speedy urbanization-behind them. They express confused sentiments resulting from frustrations with Westernization policies and the foray of wild capitalism, as much as from religious predispositions. Dissatisfaction with the Republican commitment to Westernization is not the only reason which brings Islam and Islamist writers closer to their critical mass. The issue is infinitely more complex, and is also bound up with Turkey's process of relative democratization in the 1980 s which reflected the impact of new global ideas as well as the emergence of a new breed of politicians, determined to be more liberal toward Islam. The questions asked are a product of the expansion of the public space for political Islam in the last decade and a half and of the remission in power of alternative ideologies in that space. There is also the fact that the complex middle-class shows a desire to live like Muslims in public, but may also be moved by an inability to join the consumer lifestyle and aspirations.

\section{The Influence and Effectiveness of Islamist Writers}

Can these writers set the terms of the prevalent Islamist discourse when they issue their views on ongoing problems such as Kurdish nationalism? How free, critical, and creative can they become in the process? The answers to these questions should be both in the positive and negative simultaneously. To the extent that their power and status depend on the rising appeal of Islam rather than on their involvement in a struggle as 'icons' of revolutionary organizations like the Muslim Brotherhood in Egypt or National Islamic Front in Sudan, the effect of their pronouncements are somewhat limited: they are bound to supply their 'natural' constituencies in the marketplace of Islam with what they want to hear. At the same time, to help the cause of promotion of Islam in Turkey, they are sometimes compelled to make common cause with un-Islamic elements of the society which includes secular-liberal and left-wing elements. This fact hinders Islamist writers in their effort to save Islam from being all things to all people. However, in the final analysis, they seek 'influence' in public life so as to enable Islamic politics to achieve 'control' over it. By injecting into public discourse Islamic ideas and notions, they lay the groundwork for changing the terms of political struggle.

There are a set of common concerns for these writers with regard to the Kurdish 
issue, all derived from the existing circumstances. The failure of Turkey's Islamists to shape and steer Kurdish nationalism clear of 'secular' leadership of the PKK is one critical subject of their inquiry. In doing this, they revisit and criticize the Kemalist Westernization project in terms of its effects on Kurdish nationalism. One core issue they deal with is the ethnicity-based identity emphasis of Kurdish nationalism at present. This is an especially grueling question for Islamists to come to terms with, since it presents a case which is the polar opposite of the Islamic claim to transcend ethnic particularism. Finally, they are interested in examining the motives and political performance of the Welfare Party in relation to the problem. In what follows, these themes will be examined under separate headings. The last section will attempt to offer an overall critique of the discourses analyzed.

\section{Kemalist Nationalism as a Catalyst for Kurdish Nationalism}

For the Islamist writers, the real problem facing the Muslims is not Kurdish nationalism as much as the problem of Turkish nationalism. One preoccupation of Islamist authors is to show how, throughout the Republic, Kemalist nationalism aborted the chances of an Islamist perspective to make inroads into the discourse of Kurdish nationalism. Thus, by upholding a secular, that is 'anti-religious nationalism' based on ethnicity, official Turkish nationalism contributed to the rise of its twin sister, Kurdish nationalism. The writers' arguments, on one level, acknowledge the success of the Kemalist project in terms of institutionalizing a 'state'-centered 'territorial' identity as a legitimate context for Turkey's Muslim population and political Islam. This, as we infer from the writings of the Islamist authors, Kemalist nationalism seems to have achieved on two levels: first by permeating into the consciousness of Turkey's Muslim population, its leaders and platforms, and second by monopolizing the political space.

For the writers, the most important consequence of Islamic imagination being totally penetrated by a national-secular discourse is the display of a lack of interest by 'Muslims' toward the sensibilities and claims of the Kurdish population on being regarded as a separate nation. As such, according to the writers, Kemalist invasion of the Muslim psyche revolves around two concepts, 'state' and 'territorial unity'. For Turkey's Islamic tradition, the state is historically conceptualized as a sanctified entity, as sublime and eternal (Devlet-i Ali, Devlet-i Ebed-Muddet), commanding strict loyalty and obedience to the ruler. ${ }^{10}$ The intellectual tradition of Ottoman Islam has always subscribed to the unconditional obedience to the ruler, since the Ottoman state was regarded as the institutional embodiment of the principles of Islam and the caliphate. ${ }^{11}$ The centrality of the state for the Muslim psyche was combined with the fear of dismemberment of the empire by the Christian forces, a process claimed by these writers to be in progress over the last 200 years of the empire's existence. ${ }^{12}$ It was, therefore, historically consistent for Muslim Turks to accept the state and its territorial identity of the Turkish state as the definition of a collective unity.

The question is whether or not contemporary Islamist writers ascribe to the current Turkish state the same importance and role they did to its predecessor state, even though this one no longer has particularly Islamic features. By refraining from using the word 'state' too frequently, they seem to avoid the question and draw a distinction between state on the one hand and 'regime' as the Westernized content of the state. This separation singles out the regime as the target of Islamization and leaves the state as an acceptable abstraction symbolizing an institutionalized hegemony. The borderline between these positions are, however, by no means clear-cut. 
The writers concede that this historical tradition of reverence to the state has led the past Islamic movements to put themselves at the disposal of the state. The process began after World War II when these leaders endorsed the right-wing conservative governments and their pro-Western and anti-communist causes. This culminated in a 'nationalist' state of mind on the part of Turkey's ordinary 'Muslim' citizens and their leaders. The writers fault Turkish Muslims for their refusal to look at the Kurdish conflict from a religious perspective and play into the hands of nationalist ideology.

The second pillar of Turkish official nationalist discourse, the unity and territorial integrity of the Turkish nation-state, is said to have caused 'damage' and 'distortion' in the thoughts and political orientations of Muslim people in their approach to the Kurds. ${ }^{13}$ By identifying themselves with territorial Turkish nationalism, Muslims were either quick to condemn the counter-nationalism of Kurds, or to adopt a posture of indifference to them. In the meantime they forgot that any nationalism is incompatible with the true Islamic creed which entails loyalty to the ummah. The 'nationalist reflex'14 is said to be the factor behind the failure of the Muslims to develop an 'Islamic' approach to the issue. The most striking example of this reflex is claimed to be the electoral alliance that the WP formed with the ultranationalist Nationalist Action Party (NAP) before the 1991 general elections. Ali Bulac ${ }^{15}$ characterizes this alliance as a 'telling example' (ibret verici) and as a sign that Turkish nationalism has invaded the consciousness of the Welfare Party as well ${ }^{16}$ and that even this party is more concerned with territorial unity than with a non-territorial Islam.

Islamist authors of Kurdish origin are more vocal in holding both the Turkish state and official nationalism responsible for integrating the would-be Islamic politicians into the system and turning them into supporters of the status-quo by removing the grounds for their opposition to the state. ${ }^{17}$ Upholding the sanctity of the state is less of an imperative in their minds than for the other authors. Omer Vehbi Hatipoglu, ${ }^{18}$ for example, expresses his lack of patience for 'one group of Muslims' who sympathize with the organized violence of a Syrian originated Islamic militia group, Hizbullah (The Party of God) in the Kurdish region. ${ }^{19}$ It is a well-known fact that some Muslim groups in the region supported Hizbullah's violence directed against PKK sympathizers on the grounds that the PKK was an irreligious organization. Moreover, Hizbullah was thought to have been protected or approved by the Turkish state. Hatipoglu, by rejecting Hizbullah's violence refuses any alignment with forces that are involved in bailing out the political system. For condemning the electoral deal of the WP with the NAP in 1991, another Kurdish-Islamist writer, Altan Tan uses stronger language than Ali Bulac by dubbing it 'a sellout of the Kurdish masses'. ${ }^{20}$

Overall, Islamist writers express their displeasure that Turkish Muslims have persistently ignored the Islamic dimension in interpreting the Kurdish issue and failed to address the essence of the problem, which was Republican Westernization, since it has eradicated vestiges of the Islamic presence. Meanwhile, in addition to modernization and Western influence, they also examine other historical issues that Kurdish nationalism has brought forth.

\section{Modernization, Moral Regress and Kurdish Nationalism}

All too often, Islamist writers revisit the issue of Republican modernization, which they read as Westernization, as the root cause of the Kurdish conflict. There is, however, no consensus of opinion within their ranks on the role of this Western influence in terms 
of its contribution to the radicalization of Kurdish nationalism. As such, two broad positions can be discerned among Islamist writers on the role and impact of Western cultural dominance in Turkey's Kurdish region: according to the non-Kurdish Islamist writers it is the triumph, but for most of the Kurdish authors it is the lack of triumph of Western modernity which gave impetus to a Kurdish nationalist movement against the present regime.

For the non-Kurdish Islamist writers, Western inspired secular transformation was a Turkey-wide apocalypse 'destroying the common values-read as Islamic sentiments and norms-holding the people in the region together on the basis of religion'. ${ }^{21}$ The Kemalist elite disparaged Islamic culture because they saw Islam as a 'reactionary' and 'backward' religion capable of hindering modernization. Once Islamic values were replaced by Western rules of culture and thinking, Islam lost its role as a religion calling for peace and promoting friendliness and mutual sympathy among the fellow Muslims of Turks and Kurds. As a result, brotherly feeling toward each other gave way to 'strangling each other'. ${ }^{22}$ The chief point here is similar to the basic assumption of classical modernization theory: Islam as part of tradition is removed from the public and private lives of Turks and Kurds by the onslaught of modern ideas, values and structures. Shaking off Islam has meant eliminating the unity which Islam provided among fellow Muslims. This provided the motivation for the rise of nationalist sentiment among the Kurds.

This standpoint, not unexpectedly moves on to discussing the genesis of Turkey's experiment with Westernization which became a synonym for modernization. To some, the transformation followed directly from the Second Constitutional Reform Period ${ }^{23}$ (1908-1918) when Ottoman modernization turned into Turkification policies at the hands of young Turks. Still, for others, the Kurdish question dates back to the centralization movement in Ottoman history beginning with Sultan Selim III (17611807) and gaining impetus with Mahmut II's (1808-1839) reforms. ${ }^{24}$ When we look at the historical facts on which these writers base their argument, these reforms which aimed at administrative centralization ended the informal millet-like system for the semi-independent Kurdish emirates and caused the Sufi shaikhs in the region to assume judicial and official roles, ${ }^{25}$ thus being forced to fill the authority vacuum. That is why Sufi shaikhs became the obvious focal points for the rising nationalist sentiments among the Kurds. ${ }^{26}$

Whichever reform movement they select as the genesis of the changes in the region, the writers agree that the political design of the Kemalist nation-state represented the greatest challenge to the Islamic texture in the region. ${ }^{27}$ They have in mind the series of Kurdish revolts from 1925 to 1937 , the most important one being called by the name of its leader, the (Naqshbandi) Shaikh Said revolt in 1925. Most non-Islamist researchers concur that the ostensible objective of these revolts was to bring back the Islamic character of the state which was destroyed by a series of moves, the most important of which are the abolition of the Sultanate (1923) and the caliphate (1924). At the same time the revolts had some nationalist aspirations in terms of 'holding on to ... (Kurdish) traditional identity, irrespective of whether its religious or ethnic aspect was stressed'. ${ }^{28}$

The second strand within the writers, the Kurdish authors of Islamist persuasion, maintain that neither Westernization nor nationalist ideas have really taken root among Kurds. In fact, so the argument goes, the ongoing international scenario in the Middle East aims at fostering nationalism among the Middle Eastern Kurds so as to integrate them into Western structures and consciousness and thwart the potentials of Islam. As 
Altan Tan points out: 'Kurds are the least Westernized nation in the Middle East. The threat they pose in terms of providing the impetus for an Islamic movement should be precluded ... the main goal is to push identity and religious sensibility to the background, to evoke national consciousness in Kurds and to integrate them to the West. ${ }^{29}$ 'It is a fact that due to their lesser exposure to Westernization, the Kurdish community is the least degenerated one from an Islamic perspective' stresses Yuksel. ${ }^{30}$ One symptom of the Kurdish loyalty to Islam is that nationalist aspirations which emerged at the turn of the century in the Ottoman Empire 'can not be said to have influenced the Kurds as much as it did other peoples'. ${ }^{31}$

This formulation differs from the previous one in terms of the role and importance it attaches to the Kurdish region for initiating an Islam-based upsurge. While for the previous writers the Islamic atmosphere in the heavily Kurdish region of the southeast is neither intense nor reliable, for Kurdish authors, Turkey's Kurdish population is the last remaining fortress for Islam's rigor and potential to present an alternative ideology to Kemalist Westernism. The Islamic impetus in the region is claimed to transcend ethnic perspective so that Kurdish rebellions during the Ottoman and Republican times are all seen as reactions against the wounds inflicted on religious sensibilities by the establishment of secularism, rather than as signs of assertion of ethnic identity. ${ }^{32}$ The implication is that if Kurdish nationalism achieves its final goal in setting up an independent Kurdish state, the Islamization of Turkish society will lose its momentum.

A macro critique of Islamist writers will be offered in the last section. However, two points can be made here: first, by channeling the discussion of the emergence of Kurdish nationalism to its 'root causes' identified as Ottoman-Turkish modernization, the Islamist writers shift the focus away from distribution and concentration of political power, the role of institutions and strategies of control which assume a heavy role for the evolution of Kurdish nationalism. In that sense, theirs is not a philosophical or structural critique of the history of modernization and its offspring concepts of nation, national identity, and citizenship. There is no historical and intellectual breadth in their analysis in terms of discovering the intervention of innate forces which gave rise to specific trajectories in the regime's drive to modernization without loss of its political control over the polity. Instead, spreading the contents and structures of European consciousness is assumed to give rise to what it does everywhere else, that is, the dissipation of religious values and beliefs as the most pervasive guide to moral conduct. The precondition for nationalism is then reduced to a decline in moral values caused by the onslaught of modernization.

Second, in between the lines the writers seem to charge the Republic with something more fundamental than emulating the Western culture: the Turkish nation-state was one possible model of an imagined community among other choices which were not tried out because of the imposition of this model by a narrow circle of elites. But could this particular choice also be a product of historical contingency and circumstance, and not a whimsical choice by the elite, so to speak? The question is largely unanswered except on rare moments as when Altan Tan declares: '... I don't want to discuss the wrongness or rightness of it (the Turkish nation-state), it may have been a historical process ... which is nearing an end with globalization'. ${ }^{33}$

\section{Kurdish Identity and the 'Rights-based' Claims}

The most recent perspective which dominates Kurdish popular mentality and national- 
ism is the 'identity perspective'. ${ }^{34}$ In much of the cold war period which coincided with the expansion of democracy in Turkey, however, achieving "civic and social rights" 35 with the rest of the country dominated the minds of the leaders of the Kurdish movement. Identity perspective now rejects the rights-based claims as helping the cause of Kurds' assimilation into the mainstream and as failing to recognize the value of a separate Kurdish identity.

How do the Islamist writers address the issue? It is safe to suggest that there is a divergence of opinion between the Kurdish and non-Kurdish writers on the existence and recognition of a separate Kurdish 'identity'. While the Kurdish authors see no conflict between fully subscribing to the identity claims and achieving a higher Islamic unity under the ummah, the non-Kurdish writers regard these as incompatible.

For both sets of writers, however, a 'national solution' for the Kurdish problem in the Middle East goes against the core principles of the ummah since the setting up of nation-states divides the Muslim communities in the region. On the other hand, the preferred formula of the ummah aims at establishing not only an administrative but a spiritual unity among Turks, Kurds, Iranians, Arabs and other ethnic Muslim communities in the Middle East in a way reminiscent of the late Ottoman pan-Islamic ideal. Acting on the belief that '... instead of presenting the case as a Kurdish problem, it is more fruitful to look at it as a question of restructuring the system in which Turks and Kurds live alike', ${ }^{36}$ they rule out the idea of self-determination for the Kurds as a notion totally alien to the Muslim mind, ${ }^{37}$ and that of a nation-state as illegitimate ${ }^{38}$ in principle.

The national formula is also rejected on the grounds that it represents the mirror image of Turkish nationalism, reproducing the concept of the nation based on 'race'. ${ }^{39}$ In this view, ethnic or racial claims to identity is a relational assertion which will disappear when 'the other' ethno-national identities disappear under the ummah. As for the existing Muslim nation-states, the writers totally disapprove of their separate status as independent and sovereign nations. Declares Abdurrahman Dilipak 'If ipso facto, Kuwait's right to exist as a nation-state is a serious right, one can logically argue that the same right should be extended to Kurds. But I am against the existence of Kuwait as a nation-state'. ${ }^{40}$

There is a second interpretation of the ummah which employs a discourse parallel to Turkey's left-wing platforms and which includes in its folds the Kurdish as well as the Turkish-Islamist writers. This version makes $^{41}$ explicit references to the need for respecting human rights, the rule of law and individual freedoms in the region. Still others speak of cultural rights for Kurds based on their identity: 'there is at the root of the Kurdish problem a conflict over the acceptance and confirmation of a physical and anthropological identity and of the right of this people to maintain that specific identity' says Ali Bulac. ${ }^{42}$ Even a Turkish ultranationalist renegade who has joined the ranks of Islamists admits that Kurds have a separate reality of identity and explains why his old comrades refuse to accept this: '... it is not because they believe that Kurds are Turks ... It is for their concern to keep the unity and integrity of the state'. ${ }^{43}$

Kurdish-Islamist writers take one further step and defend the constitutional guarantees for Kurdish cultural existence. Mehmet Metiner, Altan Tan, and Osman Tunc agree on this point. Metiner declares that the power-elite of today have already announced that they recognize Kurdish reality. But they have not provided a substance for it. They must provide guarantees for the cultural and national rights (of the Kurds) ... ${ }^{44}$ 'Their political identity will be constitutionally guaranteed ... This is how I envisage the cultural dimension of the problem, ${ }^{35}$ adds 'Tan, while Tunc concludes that, 
'Unless the Kurdish identity is legally and constitutionally guaranteed, political statements that have already been made will not be satisfying, meaningful and convincing'. ${ }^{46}$ At a time when identity politics has become a given in the global landscape, the ethnic origins of Kurdish Islamist writers seem to compel them to seek a space for the recognition of Kurdishness within the framework of the ummah. This they justify by referring to factors outside their control. Metiner writes in Milli Gazete, 'the problem ... is not just regional or economic ... it is also related to the dimension of a Kurdish identity. With this dimension, it is a "Kurdish" question'. ${ }^{47}$ They also propose a more liberal mode of implementing the ummah. As Tan advises, 'let us not impose an ideology and get involved in a program of modernization with a Jacobean outlook. Let us enable these people to live, speak up and liberalize themselves ... then let us leave the choice to the people ... there is Islam in the history of Turkish people. Whether or not they choose Islam today, let us not force it on them'.48

Against these liberal sounding reconstructions of Islam based on a new awareness of the identity, there are counter-arguments among the Kurdish writers, which in one specific case, echoes the well-known orientalist discourse as in the words of Sabah Kara: 'the cultural position of the Kurds is very backward';" 'if we are to form a separate state, are we in a position to bring together all the necessary components of a state? where are our novels and poetry? Those who think a civilization can be founded without poetry are wrong'. ${ }^{50}$ Kara blames Turkish nationalism for pauperizing Kurdish culture by closing the public space to Kurdish language and for reducing Kurdish people to a state of not being able to think and speak in their mother tongue. ${ }^{51}$ The writer then suggests embarking on a campaign of enlightenment to lay the ground for Kurds to demand and to protect their cultural rights. ${ }^{52}$ Similarly, another native author, Omer Vehbi Hatiboglu, rejects the idea of recognizing a separate Kurdish identity, lifting the ban on publication in Kurdish and setting up cultural institutes for the development of Kurdish language as measures serving the cause of Kurdish nationalism. ${ }^{53}$

On the whole, in attempting to find a reconciliation between Islam and the globally powerful ideas on cultural group rights, pluralism, and identities based on differences, the discourses of Islamist writers fail to produce a common meaning. How Islamic these concepts can be is a question answered differently by the authors according to their own ethnic sensibilities. An additional difficulty arises from the fact that the authors conceive society, individual liberty, self and identity by dissociating them from the autonomy of the atomized individual in his/her Western homeland. Freedom is understood within the framework of Islamic compulsions and responsibilities rather than diversity of views. Instead, the authors tend to think of these terms in relation to Islamic unity or brotherhood. The existence of a sense of a separate Kurdish identity in the minds of Kurdish writers prevent them from resolving the Kurdish problem by any consistently Islamic formula. In short, there is a breakdown of dialogue between ethnic Kurdish and non-Kurdish writers on the issue of reconciling Islamic unity with identity.

\section{The Welfare Party and its 'Attempt' to Create A Kurdish Switzerland?}

On the whole, the Islamist writers took an ambivalent attitude toward the Welfare Party as then the most significant Islamic political platform in Turkey with the most substantial support in the Kurdish region. Those writers who think that transforming the regime in an Islamic direction is a difficult task opted for offering mild warnings and informed advice to the party. But, the more radical thinking Islamist writers, who are 
not necessarily of Kurdish origin, denounced the WP's thoughts and actions on the Kurdish issue in more severe terms. The dividing line between being 'cordially distant' from the party and being 'overly critical' of it does not seem to rest on ethnic but on political persuasions.

The strongest critics of the party, for instance, were two non-Kurdish writers: Abdurrahman Dilipak and Ali Bulac. Dilipak's indictment was based on the grounds that the party, by not having a plan of action on the Kurdish question, alienated the deeply religious Kurdish population. He urged that 'the WP should disclose its program on how to solve the problem ... what are the short- and medium-range plans and strategies? Are we powerful enough to implement them ... I'm curious to find out about the WP's doctrine on the question'.54

For Ali Bulac, the problem was not just related to a programmatic deficiency, but linked to the party being permeated with Turkish nationalism. ${ }^{55}$ After the WP-led government-which was formed in June 1996-made recourse in January 1997 to another one of those investment and development packages for the southeast, which almost every government has historically resorted to in rhetoric in the past, Bulac challenged this initiative as an attempt to create a 'Kurdish Switzerland'. ${ }^{56} \mathrm{He}$ accused the WP of deviating from the Islamic path which was based on two concepts, justice and freedom: 'Is the WP suggesting a modem society or an Islamic one? Islamists are not supposed to create a new Switzerland. Islam puts emphasis on two things: justice and freedom'. ${ }^{57}$

At the same time, some Islamist writers held the opposite view: for Islamism to offer itself as an alternative to Kurdish nationalism, it should be preceded by some degree of modernization with special emphasis on infrastructural relief. Acting on the basis of a new global sensitivity toward the basic needs of people, they argued that everyday life in the region had become extremely unbearable for most Kurds in terms of poverty, homelessness (due to terror and evacuations of villages by state security forces), unemployment, and insecurity of life. They believed that the principal reason for the reluctance of the Kurdish population to coalesce around an Islamic pole-this concern was more about a moral commitment to Islam than casting votes for the WP-is the mental fatigue, despair, and helplessness of the Kurdish people caused by everyday hardship. They, therefore, urged the WP-in-government at that time to develop policies to generate income, employment, prosperity and security in the region, and more importantly, to implement the principle of the right for the Kurdish inhabitants of the region to return to their villages. ${ }^{58}$ Some of these writers contradicted Bulac's theory that creating modem life-styles and structures in the region parallel to those of Switzerland was not the right course for the party to take. Instead, by admonishing the party for its lack of programmatic resources to implement Swiss-like reforms, they helped to bring forth the critical differences within the Islamist writers, irrespective of their ethnic background.

The most provocative issues that sparkled off a fierce debate among the authors were the attempt by the WP in August 1996, to start an indirect dialogue with the PKK through some freelance Islamist intermediaries with no organizational affiliation with any existing Islamist group, and the question of the extension of the mandate on $30 \mathrm{July}$ 1996 of a US-led air force called Poised Hammer (PH) located in Turkey. ${ }^{59}$ Some writers adopted the official state line and objected to opening any dialogue with the PKK which they called 'bandits', ${ }^{60}$ while one prominent writer suggested that by choosing an emissary whose standing was dubious among Islamists, the WP had done the wrong thing for the right reasons. ${ }^{61}$ 
Renewal of the mandate of the PH as part of the Operation Provide Comfort gave rise to a more serious split among the writers' camp. One group of writers argued that this was a critical and crucial issue for the WP to prove its 'difference' vis-à-vis the other political parties. By not extending the mandate of the $\mathrm{PH}$ as it had promised to do so when in opposition, the WP could sever Turkey's over-dependence on the USA and bring forth the anti-Western tendency of the party which is central to its identity. ${ }^{62}$ Others, however, in arguing for the extension of the mandate, raised the subject of the safety of the Kurds in Northern Iraq ${ }^{63}$ and the pragmatic realities of international relations whereby Turkey needed the USA. ${ }^{64}$

Given the fact that in the post cold war era, the Turkish political context in which Islamic ideas are articulated has become more democratic than ever before, it is not surprising that divergent views have become more visible. However, the most strategic objective of the writers, then, was to prove Islam as an alternative ideology to the existing commitment of the regime to secularism, which is rooted in Western tradition. For this reason alone, differences within Islamist ranks were somehow patched up in order to avoid the impression that the Islamist camp is better at criticizing than offering a real alternative. This tactical decision helped also to explain the failure of the emergence of an unified Islamist engagement on the theoretical and empirical problematic of nationalism.

\section{Islamist Writers: What Have They Accomplished?}

There are two broad critiques that can be made of Islamist writers. First it needs to be recognized that despite the differences they display, much of the political writings by Islamist writers on Kurdish nationalism consists of a 'moral' rather than a 'political' discourse. In view of the fact that 'the political' and 'the moral' discourses are inseparably intertwined in Islam, it is understandable that the writers persistently portray a moral imagery in their writings on the Kurdish question. In fact, most of their assault on Kemalism is also on the level of 'values' and 'norms'. The authors form a strong correlation between material progress and moral regress which they hold responsible for the breakdown of unity between Turks and Kurds, who, after all, share the same religion. Furthermore, the oppression of the Kurds by the regime is explained by a crisis of morality. Emulation of Western modernity by the Republic is thought to result in the violation of Islamic precepts such as justice, wisdom, charity, and compassion as an Islamic way of life. The end result was the military solution for the problem. The substance of their discourses against the regime, their approaches to the ontological question of identity then, are moral. In that sense, the writers employ the current political impasse as a negative legitimization for an alternative Islamic model. By insisting on portraying the problem as an instance of a crisis of faith, they leave the question of what constitutes a Muslim political praxis on national question(s) open.

In trying to understand and resolve Kurdish nationalism by a vision of society based on a moral agenda derived from Islamic values and beliefs, the discourses of the authors, however, fail to convey a sense of realism in terms of offering an analysis of the past and present turmoil, chaos, poverty, and civil war in the region. Factors such as objective conditions, power relations, and institutional setup that may offer a more accurate understanding of the conflict are ignored. The end result is offering naive arguments that sometimes boil down to the view that visiting the region by Islamist writers, ${ }^{65}$ and their showing interest, sympathy, empathy, and support for the 
Muslims in the Southeast can make important contributions to the collective psyche of Kurds and pave the way to the Islamization of the Kurdish issue.

The second critique of Islamist writers is that they basically argue that any understanding of the Kurds, their history and nationalism must focus on Islam. They explain the way Kurds consented and confronted the Turkish state by a single variable: Islam. While emphasizing the continuing primacy of Islam in Kurdish communal identity, they overlook two things: the changing character of the Kurdish community vis-à-vis the larger society and the changing character of Islam. Theirs is a grossly oversimplified view of Kurds as a completely homogenous and rather backward community who express their identity in the idiom of Islam. On the whole, non-Kurdish writers basically subscribe to the view that ethnic roots can not supersede Islam, ${ }^{66}$ both in theory and also in practice. Kurds are predominantly religious and not hospitable to the Western norms inculcated by the Republic. Thus, for these writers, the most effective way to curb Kurdish nationalism is to give even more impetus to the Islamization of the Kurdish society.

Native Kurdish writers tend to deviate from this view in terms of searching for an opening for the expression of a Kurdish identity that should be constitutionally guaranteed. However, the important question is whether Islam has remained a durable and inevitable pivot of Kurdish identity at all times, not allowing Kurdish particularism-ethnicity being a fundamental marker - to show its head. This question can be rephrased: did Islam come to mean the same thing for the Kurdish people in the quite different socio-economic and political conditions of the Ottoman and Republican settings? The answers to these questions must be in the negative.

\section{Conclusion}

The Islamist writers put excessive emphasis on the pivotal role of Islam as a permanent tradition essentially opposed to nationalism. The role of Islam for Kurds-and Turks too-was dependent on specific historical forces and structures. To begin with, it is true that until the modernization attempts of the late Ottoman period took their full shape in the initial years of the Republic, Islam was an expression of Kurdish communal identity: contrary to the majority Turks who belong to the Hanafi school of Sunni Islam, the Kurds have mostly followed the Shafi'i school of Sunni Islam. They were known to be more religious and members of the Khalidiya branch of the Naqshbandi tarikat (a Sufi brotherhood).$^{67}$ Beginning from the eighteenth century, the high profile of Khalidiya shaikhs (the leaders of tarikats), their madrasahs (religious seminaries), and mullahs (the teachers at the madrasahs) provided the central values and the particular ways of thinking and behaving as a Kurd. Without this Islamic connection, Kurdish primordial existence was meaningless. These two components overlapped ${ }^{68}$ and became 'part of a continuum'. ${ }^{69}$

Islam became salient only under these specific conditions because it was not just a symbolic category but was grounded in societal existence. The conditions of that existence began to change from the 1930s: suppression of the tarikats shattered the power of Khalidiya shaikhs and 'the learning and socio-political activity ${ }^{70}$ of the tarikats in the madrasahs. As a result, the new genre of shaikhs became less qualified and more cooptable by the regime. But before that, the discontent of the Khalidiya shaikhs against the secularization measures was translated into revolts through an Islamic discourse. Islam for Turkey's Kurds became 'the identity of resistance ${ }^{71}$ to the regime at a specific 
point of time when communal Islam provided the parameters of a shared identity. The salience of Islam, in other words, was conjuncture-specific.

The relatively deeper integration of the Southeast into mainstream Turkey under a more pluralist political configuration in the cold war period provided the context for a new social existence for the Kurds. Kurdish community was imagined differently in the $1930 \mathrm{~s}, 1960 \mathrm{~s}$, and $1990 \mathrm{~s}$ in reaction to Turkish nationalism, modernization and globalization, respectively. A new actor, a secular Kurdish intelligentsia, was added to the existing group of tribal chiefs and shaikhs. The power of the shaikhs declined and the tribal leaders were coopted by the system so as to help the government in the suppression of Kurdish nationalism. ${ }^{72}$ As a result, the secular Kurdish intelligentsia became the obvious focal point of nationalist sentiments. The new Kurdish nationalist leaders were more concerned about obtaining 'civic and social rights" ${ }^{73}$ than asserting a specific Kurdish identity based on Islam. In most of the 1960s and 1970s, 'the paths of Kurdish nationalism and of Kurdish folk Islam were destined to part company. When both resurfaced ... the shaikhs generally encouraged their disciples to support conservative clerical or right-wing parties in national politics; Kurdish nationalists, on the other hand, sought strength from the political left' ${ }^{74}$

Meanwhile, the ways in which Islam was reinvented have also changed. The role of Islam as an identity marker in terms of drawing the boundaries of the imagined community of Kurds $v i s-\grave{a}$-vis the ethnic Turkish community declined. At the same time, however, the visibility of Islam in Turkey has risen. Why is it that the rising public appeal of Islam has had limited influence on Kurdish nationalism? There are at least three explanations for this seeming paradox. In conditions of a global social existence, Islam ceases to be equated exclusively with the discontent of a narrow community but is a conduit for the expression of a more complex reality for the larger society. Islamic opposition under such conditions is diffused throughout the larger community and articulates larger-scale resentments and identities stemming from the crisis of the 'modem' nation state. Second, it becomes clear that a pivotal role for Islam in a Kurdish political movement was dependent upon the existence and availability of 'purposive agents such as the ulama $^{\text {?75 }}$ passing through Naqshbandi seminaries. When the Republican system of education made no room for Islam and promoted a positivist, non-religious education in its place, religion as the embodiment of the Kurdish identity assumed a declining role. Third, Sufism lost its significance as a means of unifying Kurdish society. All these lend support to the broad claim that Islam is not an actor to do something; rather it is a discursive tradition socially produced by Muslims themselves'. ${ }^{76}$

Overall, the assertion of Kurdishness today is being made not by referring to Islam but 'to a set of cultural artifacts stemming from social relations' ${ }^{77}$ This suggests that structures of feeling 'different' are complex historical products of global, regional, national, and local pressures and interactions. Islam in its current politicized stage fails to provide for the Kurds the logic of externalizing the Turkish Other and turns out to play a binding rather than dividing role for the two communities.

\section{Acknowledgements}

I would like to thank Hakan Yavuz, Elizabeth Prodromou, Rifa'at Abou-El-Haj, William Blair and Herro Mustafa for spending some of their scarce and valuable time for making constructive and insightful comments and criticisms on an earlier draft of this manuscript. 


\section{NOTES}

1. They are Ali Bulac, Abdurrahman Dilipak, Abdullah Guney, Omer Vehbi Hatipoglu, Sabah Kara, Fehmi Koru, Mehmet Metiner, Mehmet Pamak, Ahmet Tasgetiren, Altan Tan, Osman Tunc and Mufit Yuksel. Occasional references are made to writers who have written on the topic less frequently.

2. They are Osman Tunc, Altan Tan, Sabah Kara, Mehmet Metiner, Omer Vehbi Hatipoglu, and Abdullah Guney.

3. Although the writers in question prefer to be called 'Muslim writers', in this article, to denote these writers, the term Islamist writers will be used. Among the 12 writers whose published views on Kurdish nationalism were analyzed, Ali Bulac is certainly a Muslim intellectual (the term the people in this category use to describe themselves) in terms of being a central figure in the key process of reconfiguring the core ideas of Islam so as to make them available. For an in-depth explanation of their background and approach see Michael Meeker, 'The New Muslim Intellectuals in the Republic of Turkey', in, Islam in Modem Turkey-Religion, Politics and Literature in a Secular State, ed. Richard Tapper, London: I. B. Tauris \& Co. Ltd., 1991.

4. The Welfare Party collected a $\mathbf{3 2 . 2 \%}$ as opposed to its first-place showing in Central Anatolia which was $36.8 \%$. Its third largest share of regional votes was again in the southeast $(24.2 \%)$. In contrast, the Kurdish party, the People's Labor Party, received only 3.7\% of its overall votes in the east and $17.6 \%$ in the southeast. The party was outlawed on 16 January 1998 by the Constitutional Court and reentered politics under the banner of the newly formed Virtue Party (Fazilet Partisi).

5. In 1991, PKK's leader, Abdullah Ocalan published a book under the pseudonym of Ali Firat, called 'Din Sorununa Devrimci Yaklasim' (A Revolutionary Approach to the Issue of Religion). In the book, he acknowledged that Islam can play a progressive role in the Middle East in any anti-imperialist struggle as is the case with the PKK's nationalism. The second printing of the book appeared in 1993 with Abdullah Ocalan's name appearing on the cover and Dr. Ali Kucuk as the editor.

6. Hamit Bozarslan, 'Kurt Milliyetciligi Islama Siginiyor' (Kurdish Nationalism is Seeking Refuge under Islam), Yeni Yuzyil (Turkish daily), 12 July, 1996.

7. Dale F. Eickelman and James Piscatori, Muslim Politics, Princeton: Princeton University Press, 1996, pp. 37-45.

8. Ibid., p. 38.

9. Ibid., p. 43.

10. Abdullah Guney in Kurd Sorusturmasi (Investigation on Kurds), Ankara: Sor Yayincilik, 1992, p. 42.

11. Ali Bulac, 'Islami Bir Perspektiften Kurt Sorunu' (The Kurdish Problem from an Islamic Perspective), Kitap Dergisi, March-April 1992, No. 61-62, p. 31.

12. Ali Bulac, 'Muslumanlarin Kurt Sorununa Bakislari (2)' (The Kurdish Problem from Muslims' Perspectives), Yeni Safak (Turkish Daily), 14 March 1996.

13. Omer Vehbi Hatipoglu, Bir Baska Acidan Kurt Sorunu (The Kurdish Problem from a Different Perspective), Ankara: Mesaj Yayinlari, 1992, p. 162.

14. Ahmet Tasgetiren, 'Bir Dokun Bin Ah Isit' (Tap Once, Hear a Thousand Complaints), Yeni Safak; 6 Subat 1996; Ali Bulac, 'Kurtlerin Gelecegi' (The Future of Kurds), Yeni Safak, 31 July 1996.

15. Sami Zubaida, in his article 'Turkish Islam and National Identity' Middle East Report, 2, April-June 1996, p. 14, calls Ali Bulac, Ismet Ozel, Rasim Ozdenoren and llhan Kutluer as being fully acquainted with the main trends in Western thought, and 'well-informed and thoughtful "postmodernists" (in the literal sense of the term rather than in the sense of espousing post-modernist theories)'.

16. Bulac in Kurd Sorusturmasi, op. cit., p. 95.

17. Guney in ibid., p. 39; Pamak in ibid., p. 344; Bulac, 'Muslumanlarin Kurt Sorununa Bakislari (2)'.

18. He was a Kurdish member of parliament for the Welfare Party, representing the prominently Kurdish province of Diyarbakir, speaking and writing vocally about the specific grievances of the local people and advocating an 'Islamic nationalism' as the way out.

19. Hatipoglu, Bir Baska Acidan Kurt Sorunu, op. cit., p. 167.

20. Tan in Kurd Sorusturmasi, op. cit., p. 125.

21. Bulac in Kurd Sorusturmasi, op. cit., p. 109; a similar view is expressed by Omer Vehbi Hatipoglu in Kurd Sorusturmasi, op. cit., p. 398.

22. Ibid. 
23. Hatipoglu in Kurt Sortusturmasi, op. cit., p. 398.

24. Mehmet Metiner in Kurt Sorunu Nasil Cozulur? (How Can the Kurdish Problem be Solved?), Istanbul: Nubihar Yayinlari, 1996, p. 35; Mufit Yuksel, Kurdistanda Degisim Sureci (The Process of Change in Kurdistan), Ankara: Sor Yayincilik, 1993, p. 375.

25. Martin van Bruinessen, Agha, Shaikh and State: The Social and Political Structure of Kurdistan, London: Zed Books, 1992, p. 230.

26. Ibid.

27. Bulac in Kurt Sorunu Nasil Cozulur?, op. cit., p. 105; Tasgetiren in ibid., p. 94; Tan in ibid., p. 72; Abdurrahman Dilipak, in Kurt Sorunu-Aydinlarimiz Ne Dusunuyor? (The Kurdish QuestionWhat Do Our Intellectuals Think?), ed. Metin Sever, Istanbul: Cem Yayinevi, 1992, p. 120-121.

28. Martin van Bruinessen, 'Popular Islam, Kurdish Nationalism and Rural Revolt: The Rebellion of Shaikh Said in Turkey (1925)' in Religion and Rural Revolt, ed. Janos M. Bak and Gerhard Banecke, Manchester, New Hampshire: Manchester University Press, 1984, pp. 281-295. The same point is shared by Hamit Bozarslan, 'Political Aspects of the Kurdish Problem in Contemporary Turkey', in The Kurds-A Contemporary Overview, ed. Philip G. Kreyenbroek and Stefan Sperl, London and New York: Routledge, 1992, p. 96.

29. Tan in Kurd Sorusturmasi, op. cit., p. 118.

30. Yuksel, Kurdistanda Degisim Sureci, op. cit., p. 389.

31. Ibid., p. 193.

32. Ibid., p. 194.

33. Tan in Kurt Sorunu Nasil Cozulur? op. cit., p. 72.

34. This is one of the conclusions of a report published by a powerful state-friendly economic interest group, The Union of Turkish Chambers of Commerce and Commodity Exchanges (TOBB), published in July 1995. According to the report, $40.3 \%$ of the Kurdish respondents refer to Kurdish ethnicity as the basis of their identity, as opposed to only $22.3 \%$ who identify themselves as Turkish.

35. Bozarslan, 'Political Aspects of the Kurdish Problem in Contemporary Turkey', op. cit., p. 99.

36. Tasgetiren in Kurt Sorunu Nasil Cozulur? op. cit., p. 94.

37. Bulac in Kurt Sorunu-Aydinlarimiz Ne Dusunuyor? op. cit., p. 99.

38. Tan in Kurd Sorusturmasi, op. cit., p. 132.

39. Hanpoglu, Bir Baska Acidan Kurt Sorunu, op. cit., p. 30.

40. Dilipak in Kurt Sorunu-Aydinlarimiz Ne Dusunuyor?, op. cit., p. 115.

41. Bulac in ibid., p. 102; Dilipak in ibid., p. 84 .

42. Bulac in ibid., p. 98.

43. Pamak in Kurd Sorusturmasi, op. cit., p. 328.

44. Metiner in Kurt Sorunu Nasil Cozulur? op. cit., p. 38.

45. Tan in ibid., p. 73.

46. Tuac in ibid., p. 144.

47. Mehmet Metiner, 'Refahin Guneydoguya Iliskin Duyarliligi' (Sensitivity of Welfare Party Related to the Southeast), Milli Gazete (Turkish Daily), 27 August 1996.

48. Tan in Kurt Sorunu Nasil Cozulur? op. cit., p. 77.

49. Kara in ibid., p. 54.

50. Ibid., p. 57.

51. Ibid., p. 53.

52. ibid., p. 56 .

53. Hatipoglu, Bir Baska Acidan Kurt Sorunu, op. cit., pp. 179-180.

54. Abdurrahman Dilipak, 'Erbakan Doktrini' (The Erbakan Doctrine), Akit; 25 July 1996.

55. Bulac in Kurd Sorusturmasi, op. cit., p. 95.

56. Ali Bulac on a TV interview on Channel 7, 28 August 1996.

57. Ibid.

58. Kemal Ozturk, 'Heyecan Yerini Hesaba Birakmis' (The Enthusiasm Has Been Replaced by Cautiousness), Yeni Safak 20 July 1996; Yilmaz Yalciner, 'Cozum Arayisini Desteklemeliyiz' (We Have to Support the Search for A Solution), Akit 8 August 1996; Ali Bulac, 'RP'den Beklentiler' (Expectations from the WP), Yeni Safak 25 July 1996.

59. Poised Hammer (PH) is part of the Operation Provide Comfort (OPC) launched in Spring of 1991 by US leadership (backed by Great Britain, Turkey and France) when Saddam Hussein put down a rebellion by Kurds, forcing 300000 to flee to Turkey. The OPC set up a safe haven for Kurds in Northern Iraq and declared a no-flight zone for Saddam north of the 36th parallel. The OPC 
consisted of a US-led air force based in Turkey, Poised Hammer, that patrols the protected zone and is subject to extension by Turkish parliament every 6 months; a small military force in Zakho in Northern Iraq and relief aid distributed to Kurds in Northern Iraq. The WP led government extended the mandate of PH on 30 July 1996. Meanwhile, on 31 August, Saddam Hussein shifted his policy in the north and aligned himself with one of the waning factions of Kurds-with Barzani-against the other. Turkey supported this complicity with the hope that Barzani forces would crack down on the PKK entrenched in the area. This change of policy made the American policy of creating a safe haven in Northern Iraq almost unnecessary so that the presence of $\mathrm{PH}$ ended on 31 December, 1996, and OPC was cut down in size. This development took place not because the WP wanted, but because the balance of power changed in the region. The PH was replaced by Operation Northern Watch.

60. See Huseyin Gulerce, 'Son Girisim Bir Tuzak Mi?' (Is the Last Attempt an Ambush?), Zaman, 8 August 1996; Osman Guzelgoz, 'PKK'yi Muhatap Kabul Etmek Dogru Mu?' (Is It Right Considering to Speak to PKK?), Zaman, 8 August 1996.

61. The emissary is Ismail Nacar, the objector is Fehmi Koru ['Dogru Hedef Yanlis Arac' (Target is Right, But the Means is Wrong), Zaman, 5 August 1996].

62. Ahmet Tasgetiren, 'Cekic Guc 5. Ordu Olsun' (Let the Poised Hammer Be the 5th Army of Turkey), Yeni Safak, 22 March 1996; Ahmet Tasgetiren, 'Necmeddin ve 15 Arkadasi Icin' (For Necmetin Erbakan and His 15 Friends), Yeni Safak, 30 July 1996; Omer Furkan Nezir, 'RP'nin Ilk Iktidar Testi: Cekic Guc' (The First Test of WP in Power: Poised Hammer), Yeni Safak, 20 July 1996; Ahmet Selim, 'Bu Hikaye Bitmeli' (This Story Must Come to an End), Zaman, 24 July 1996; Abdurrahman Dilipak, 'Erbakan Doktrini' (The Erbakan Doctrine), Akit 25 July 1996.

63. Ali Bulac, 'Cekic Guce Neden Ihtiyac Var?' (Why is Poised Hammer Necessary?), Yeni Safak; 30 July 1996; Abdurrahman Dilipak, 'Bayrak Olayi' (The Flag Phenomenon) Akit; 26 June 1996.

64. Yasar Kaplan, 'Cekig Gucte Yeni Egilimler' (New Tendencies in Poised Hammer), Akit 29 July 1996.

65. Ahmet Tasgetiren reports the bad feeling he encountered in Diyarbakir about Muslim writers, in particular Ali Bulac, not going to the region (Tasgetiren in 'Bir Dokun Bin Ah Isit', op. cit.). Ironically enough, 10 months later, the writer in question, Ali Bulac, also complains about lack of interest by the 'Islamic milieau outside the southeast' in the region (Ali Bulac, 'Guneydogunun Psikolojisi', Yeni Safak, 6 December, 1996).

66. Bulac in Kurd Sorusturmasi, op. cit., p. 104.

67. Martin van Bruinessen suggests that though founded in the 13th century, this tarikat came to the region much later. Other branches of Naqshbandi tarikat have existed in the region since the seventeenth century. However, it was only after the proselytising activities of Mawlana Khalid in the first quarter of the nineteenth century that the Khalidiya took prominence over other tarikats, Qadiriya being the chief one. See Martin van Bruinessen, 'The Naqshbandi Order in Seventeenth Century Kurdistan', in Marc Gaborieau, et. al., (eds.), Naqshbandis; Istanbul: ISIS Yayincilik, 1990. Similarly, Hamid Algar traces the Turkish connection with the Naqshbandiya to the 15th century: Hamid Algar, 'The Naqshbandi Order in Republican Turkey', Islamic World Report, Vol. 1, No. 3, 1996, p. 52.

68. van Bruinessen, Agha, Shaikh and State: The Social and Political Structure of Kurdistan, op. cit., p. 7.

69. Lale Yalcin Heckmann, 'Ethnic Islam and Nationalism Among the Kurds in Turkey', in Richard Tapper (ed.), Islam in Modern Turkey-Religion, Politics and Literature in a Secular State, London and New York: I. B. Tauris and Co. Ltd., 1991, p. 118.

70. Algar, 'The Nagshbandi Order in Republican Turkey', op. cit., p. 62.

71. Hakan Yavuz, 'The Patterns of Political Islamic Identity: Dynamics of National and Transnational Loyalties and Identities', Central Asian Survey, Vol. 3, 1995, p. 355.

72. Robert Olson, 'The Creation of a Kurdish State in the 1990s?', fournal of South Asian and Middle Eastern Studies, Vol. XV, No. 4, Summer, 1992, p. 14.

73. Hamit Bozarslan, 'Political Aspects of the Kurdish Problem in Contemporary Turkey', in The Kurds-A Contemporary Overview, eds Philip G. Kreyenbroek and Stefan Sperl, London: Routledge, 1992, p. 99.

74. David McDowall, A Modern History of the Kurds; London: I. B. Tauris and Co. Ltd., 1991, p. 211.

75. Yavuz, op. cit., p. 341.

76. Ibid., p. 368.

77. Ibid., p. 341 . 